\title{
Duration of the effects of scarification and raised bed associated with vegetation cover on soybean yield on an Alfisol
}

\author{
Silvana Spaniol Fin(1), Enio Marchesan(1), Paulo Ivonir Gubiani(1), João Alberto Pedroso Farenzena(1), \\ Marcos Stefanello Murari(1), Lucas Lopes Coelho(1), Alberto Cargnelutti Filho ${ }^{(1)}$ and Bruno Behenck Aramburu ${ }^{(1)}$ \\ (1)Universidade Federal de Santa Maria, Avenida Roraima, № 1.000, Cidade Universitária, Camobi, CEP 97105-900 Santa Maria, RS, \\ Brazil. E-mail: silvana_fin@hotmail.com, eniomarchesan@gmail.com, paulogubiani@gmail.com, ja.farenzena@hotmail.com, \\ marcos.murari@hotmail.com, lucas_I_c@hotmail.com, alberto.cargnelutti.filho@gmail.com, bruno.behenck@gmail.com
}

\begin{abstract}
The objective of this work was to determine the duration of the effects of the mechanical interventions scarification and raised bed on soybean (Glycine max) grain yield on an Alfisol, as well as to evaluate, through physical indicators, if the use of cover plants during winter increases the duration of these effects. The experimental design was a complete randomized block with four replicates. Two factors were evaluated. The first consisted of types of soil preparation systems: $\mathrm{SC}_{14}$, scarification in November 2014; $\mathrm{SC}_{15}$, scarification in November 2015; $\mathrm{RB}_{14}$, raised bed built in November 2014; and $\mathrm{RB}_{15}$, raised bed built in November 2015. The second consisted of the type of cover crop used: winter fallow, oat, ryegrass, and wheat. From November 2015 to April 2016, soybean was cultivated under the different soil preparation systems. Soil density, total porosity, macroporosity, microporosity, soil saturated hydraulic conductivity, soil resistance to mechanical penetration, and soybean grain yield were evaluated. There was no effect of cover plants after one crop season on the maintenance of soil physical attributes. Changes in soil density, total porosity, and resistance to mechanical penetration, promoted by scarification, are noticeable up to at least 18 months. The continuance of these modifications reflects in soybean grain yield in the second harvest.
\end{abstract}

Index terms: Glycine max, crop rotation, rice areas, soil compaction, soil preparation.

\section{Duração dos efeitos de escarificação e camalhão associados à cobertura vegetal na produção de soja em Planossolo}

Resumo - O objetivo deste trabalho foi determinar o tempo de duração dos efeitos das intervenções mecânicas escarificação e camalhão no rendimento de grãos de soja (Glycine max) em um Planossolo, bem como avaliar, por meio de indicadores físicos, se o uso de plantas de cobertura no período do inverno aumenta a duração destes efeitos. O delineamento experimental foi de blocos ao acaso com quatro repetições. Foram avaliados dois fatores. $\mathrm{O}$ primeiro consistiu do tipo de preparo do solo: $\mathrm{ES}_{14}$, escarificação em novembro de 2014; $\mathrm{ES}_{15}$, escarificação em novembro de 2015; $\mathrm{CA}_{14}$, camalhão construído em novembro de 2014; e $\mathrm{CA}_{15}$, camalhão construído em novembro de 2015. O segundo consistiu do tipo de cobertura: pousio no inverno, aveia, azevém e trigo. De novembro de 2015 a abril de 2016, cultivou-se soja sob os diferentes preparos do solo. Foram avaliados densidade do solo, porosidade total, macroporosidade, microporosidade, condutividade hidráulica do solo saturado, resistência do solo à penetração mecânica e rendimento de grãos de soja. Não foi detectado efeito de plantas de cobertura, em um único ano de cultivo, na manutenção dos atributos físicos do solo. Alterações na densidade, na porosidade total e na resistência do solo à penetração, promovidas pela escarificação mecânica, são perceptíveis por no mínimo 18 meses. A persistência dessas modificações reflete no rendimento de grãos de soja na segunda safra.

Termos para indexação: Glycine max, rotação de culturas, área de arroz, compactação do solo, preparo do solo.

\section{Introduction}

In the state of Rio Grande do Sul, Brazil, Alfisols cover approximately $56 \%$ of the floodplain soil areas, representing about $11 \%$ of the state. In recent years, there has been a growing interest in the use of soybean [Glycine max (L.) Merr.] to control weeds in flood-irrigated rice (Oryza sativa L.) fields planted in these areas, since it allows using herbicides with different mechanisms of action (Missio et al., 2010). In the 2015/2016 crop season, approximately 270 thousand hectares of soybean were sown in the rice paddy fields in the state (IRGA, 2016). The soils there are characterized by natural density, high micropore/
Pesq. agropec. bras., Brasília, v.53, n.11, p.1230-1238, Nov. 2018 DOI: 10.1590/S0100-204X2018001100005 Creative Commons Attribution 4.0 International License 
macropore ratio, drainage deficiency mainly due to the low hydraulic conductivity of the B horizon or to the underlying material, and compacted subsurface layer (Gomes et al., 2006); in and below this layer, it is difficult for roots to extract water and nutrients from the soil (Calonego et al., 2011), which can affect soybean grain yield.

To minimize compaction, scarification systems are commonly used in order to reduce soil density, microporosity, and the micropore/macropore ratio, as well as to increase macroporosity and total porosity (Sartori et al., 2015; Giacomeli et al., 2016). Among the practices adopted to improve water drainage, stand out using sloping ground to build raised beds, aiming at more efficient drainage and irrigation (Silva et al., 2008). Soil preparation through scarification and raised beds, therefore, provides an environment that facilitates the drainage and aeration of the root system, resulting in greater soybean yields on Alfisols (Sartori et al., 2015).

One of the limitations of using these soil preparation systems, however, is the ephemerality of their benefits on soil properties (Álvarez et al., 2009), since soil reconsolidation occurs naturally; this process is intensified if preventive measures are not taken (Abreu et al., 2004). In this case, cover crops can be used to prolong the benefits of soil decompression, complementing the rupture of the compacted soil layer. According to Nicoloso et al. (2008), biomass and its residues protect soil surface, whereas root decomposition forms biopores that facilitate air and water flow in the soil.

Nicoloso et al. (2008), for example, found an increase in soil macroporosity, a decrease in soil penetration resistance, and an improvement in water infiltration in an Oxisol planted with radish (Raphanus sativus L.) and black oat (Avena strigosa Schreb.) crops during winter. Drescher et al. (2016) observed that, after mechanical scarification in an Oxisol, the changes in the properties indicative of soil structure, such as density, total porosity, and macroporosity, lasted less than a crop season, but that the effects of scarification were maintained for up to 24 months for properties related to water transport, including hydraulic conductivity and stable infiltration rate of water in the soil; therefore, these indicators are more sensitive for evaluating the duration of mechanical decompression. Moreover, Nunes et al. (2014) reported that, in an Ultisol, the positive effects of scarification on soil density and degree of compaction did not last for more than 18 months.

Therefore, management practices that improve soil aeration and drainage, such as the cultivation of cover crops during winter, could be explored as alternatives to promote the adoption of conservation systems and to guarantee the yield stability of soybean in floodplain areas.

The objective of this work was to determine the duration of the effects of the mechanical interventions scarification and raised bed on soybean grain yield on an Alfisol, as well as to evaluate, through physical indicators, if the use of cover plants during winter increases the duration of these effects.

\section{Materials and Methods}

The experiment was conducted from the 2014/2015 crop season until the 2015/2016 summer harvest, in the experimental floodplain area located in the Plant Science Department of Universidade Federal de Santa Maria, in the municipality of Santa Maria, in the state of Rio Grande do Sul, Brazil $\left(29^{\circ} 43^{\prime} \mathrm{S}, 53^{\circ} 43^{\prime} \mathrm{W}\right.$, at 90 $\mathrm{m}$ of altitude). The soil in the area is classified as a Planossolo Háplico eutrófico arênico (Santos et al., 2013), i.e., a sandy Eutrophic Haplic Alfisol.

The experimental design was a randomized complete block with four replicates in a paddy rice production area. In November 2014, each block was divided into four strips with $19.2 \mathrm{~m}$ length and $3.5 \mathrm{~m}$ width; each strip received the following soil preparation systems (first treatment factor): $\mathrm{SC}_{14}$, scarification at $0.25-\mathrm{m}$ depth; $\mathrm{RB}_{14}, 0.1-\mathrm{m}$ high raised beds, with $1.0-\mathrm{m}$ spacing between them; and $\mathrm{DD}_{14}$, double-disk (two strips) opener. Between November 2014 and April 2015 , the strips were cultivated with soybean. After soybean harvest in April and May 2015, four strips of $14 \mathrm{~m}$ length and $4.8 \mathrm{~m}$ width, perpendicular to the soil, also received the following cover crops (second treatment factor): black oat (Avena sativa L.), ryegrass (Lolium multiflorum Lam.), wheat (Triticum aestivum L.), and fallow (control).

A total of 50 and $80 \mathrm{~kg} \mathrm{ha}^{-1}$ ryegrass and oat seeds, respectively, were broadcast seeded in April 2015. Wheat was sown in rows on May 21, 2015, at a density of 300 seeds per square meter. Harvested black oat and ryegrass plants were desiccated on October 26, 2015, 
and the average shoot dry matter was 2,839 and 3,900 $\mathrm{kg} \mathrm{ha}^{-1}$, respectively. Wheat was harvested on October 19,2015 , with an average grain yield of $1,693 \mathrm{~kg} \mathrm{ha}^{-1}$, and then desiccated.

In November 2015, the two strips prepared with $\mathrm{DD}_{14}$ were also subjected to scarification $\left(\mathrm{SC}_{15}\right)$ and raised beds $\left(\mathrm{RB}_{15}\right)$. Seeds of the soybean cultivar BMX Valente RR (6968 RSF) were sown at a density of 28 seeds per square meter throughout the experimental area in this same month. However, because of the low emergence of plants due to excessive rainfall, reseeding was performed on December 7, 2015. The seeds were treated with a mixture of $25 \mathrm{~g} \mathrm{~L}^{-1}$ pyraclostrobin, $225 \mathrm{~g} \mathrm{~L}^{-1}$ thiophanate-methyl, and 250 $\mathrm{g} \mathrm{L}^{-1}$ fipronil, at a dosage of $200 \mathrm{~mL}$ per $100 \mathrm{~kg}$ seeds, and were inoculated with Bradyrhizobium japonicum strains at a dosage of $100 \mathrm{~g}$ per $50 \mathrm{~kg}$ seeds. The basic fertilizer applied consisted of $17.5 \mathrm{~kg} \mathrm{ha}^{-1} \mathrm{~N}, 70 \mathrm{~kg} \mathrm{ha}^{-1}$ $\mathrm{P}_{2} \mathrm{O}_{5}$, and $70 \mathrm{~kg} \mathrm{ha}^{-1} \mathrm{~K}_{2} \mathrm{O}$, defined according to the recommendations of the manual of fertilization and liming of Comissão de Química e Fertilidade do Solo (Tedesco et al., 2004). Because of reseeding, a further $48 \mathrm{~kg} \mathrm{ha}^{-1} \mathrm{~K}_{2} \mathrm{O}$ were applied in the $\mathrm{V} 6$ vegetative stage (Fehr \& Caviness, 1977).

For $\mathrm{SC}_{14}, \mathrm{RB}_{14}$, and $\mathrm{SC}_{15}$, seeding was done with the MF 407 mechanical planter (Massey Ferguson, AGCO, Duluth, GA, USA), in six rows spaced $0.50 \mathrm{~m}$ apart, using a smooth disk for cutting straw and a double disk for fertilizer deposition. For $\mathrm{RB}_{15}$, the Hyper Plus raised-bed planter (Industrial KF, Cândido Godói, RS, Brazil) was used, with seeding also in six rows spaced $0.50 \mathrm{~m}$ apart, with a smooth disk for cutting straw and a rod and shank fertilizer opener, consisting of three moldboards for the formation of raised beds with two furrows on the edge of each elevation.

Soil samples with preserved structure were collected to determine soil bulk density, total porosity, macroporosity, and microporosity in: November 2014, after $\mathrm{SC}_{14}, \mathrm{RB}_{14}$, and $\mathrm{DD}_{14}$; April 2015, after the first soybean crop harvesting and before sowing of cover crops; in December 2015, after $\mathrm{SC}_{15}$ and $\mathrm{RB}_{15}$; and April 2016, after the second soybean crop. Soil samples were collected at the soybean sowing row and at the depths of 0-10 and 10-20 cm (one sample per layer). The samples were then saturated by capillary action, weighed, and placed in a sand column under a tension of $6.0 \mathrm{kPa}$ (Reinert \& Reichert, 2006). After being drained, the samples were reweighed, and those collected in
December 2015 were re-saturated and subjected to the analysis of saturated hydraulic conductivity (Ks, $\mathrm{mm} \mathrm{h}^{-1}$ ), which was determined under constant load permeability, following the method described by Libardi (2005). Finally, the soil samples were placed in an oven at $105^{\circ} \mathrm{C}$. Soil bulk density $\left(\mathrm{g} \mathrm{cm}^{-3}\right)$ was calculated by dividing dry soil mass by soil sample volume. Total porosity $\left(\mathrm{cm}^{3} \mathrm{~cm}^{-3}\right)$ was obtained from the relationship between volumetric water content at saturation and sample volume; microporosity $\left(\mathrm{cm}^{3} \mathrm{~cm}^{-3}\right)$, from the relationship between volumetric water content at $60 \mathrm{kPa}$ and sample volume; and macroporosity $\left(\mathrm{cm}^{3} \mathrm{~cm}^{-3}\right)$, from the difference between total porosity and microporosity.

Soil resistance to mechanical penetration (RP, $\mathrm{MPa}$ ) was determined in December 2015, after soybean sowing, and in April 2016, at the end of the soybean development cycle, for $\mathrm{RB}_{14}, \mathrm{SC}_{14}, \mathrm{RB}_{15}$, and $\mathrm{SC}_{15}$. $\mathrm{RP}$ was measured in the layer of $0-30 \mathrm{~cm}$, using the PLG 1020 digital penetrograph (Falker, Porto Alegre, RS, Brazil), at eight equidistant points - six between rows and two in the sowing grooves - arranged perpendicularly to the sowing rows and $0.167 \mathrm{~m}$ apart. When the RP data were acquired, surface graphs were generated. Grain yield was determined only in the second soybean crop, by manually harvesting a $4-\mathrm{m}^{2}$ area, expressed based on $13 \%$ water content.

Data were subjected to the analysis of variance, preceded by the analyses of normality and homogeneity of variances, performed by the F-test. For soil bulk density, total porosity, macroporosity, and microporosity, the combined effect of soil preparation and application times (first set of treatments) was evaluated, compared with $\mathrm{DD}_{14}$ (reference), using Dunnett's test, at 5\% probability. This analysis was carried out separately for each cover crop. For grain yield and hydraulic conductivity, the combined effect of soil preparation and cover crop (second set of treatments) was assessed, using Tukey's test, also at $5 \%$ probability.

\section{Results and Discussion}

In the $0-10-\mathrm{cm}$ layer, there was a significant effect of raised beds and scarification on soil bulk density (Table 1) and total porosity (Table 2), which decreased for macroporosity (Table 3) and microporosity (Table 4). 
When differences were significant, scarification and raised beds decreased soil bulk density and increased total porosity, macroporosity, and microporosity, compared with the treatment $\mathrm{DD}_{14}$ in 2014. Regardless of the cover crop cultivated after scarification and raised-bed formation in November 2014, the values for soil bulk density, total porosity, and microporosity were maintained for 18 months, up to April 2016, and differed significantly from those obtained after the $\mathrm{DD}_{14}$ treatment. The same effect was observed for macroporosity after the $\mathrm{SC}_{14}$ treatment, but only in plots that had been cultivated with wheat during fallow,

Table 1. Soil bulk density measured in the layers of 0-10 and 10-20 cm in November 2014, April 2015, December 2015, and April 2016, after soil preparation ${ }^{(1)}$ and the use of cover crops in the winter, in the experimental area in the municipality of Santa Maria, in the state of Rio Grande do Sul, Brazil.

\begin{tabular}{|c|c|c|c|c|c|c|c|c|c|c|c|c|c|c|}
\hline \multirow[t]{2}{*}{${\text { Cover } \text { crop }^{(2)}}$} & \multicolumn{3}{|c|}{ November 2014} & \multicolumn{2}{|c|}{ April 2015} & \multicolumn{4}{|c|}{ December 2015} & \multicolumn{4}{|c|}{ April 2016} & \multirow{2}{*}{$\begin{array}{l}\mathrm{CV} \\
(\%)\end{array}$} \\
\hline & $\mathrm{DD}_{14}$ & $\mathrm{SC}_{14}$ & $\mathrm{RB}_{14}$ & $\mathrm{SC}_{14}$ & $\mathrm{RB}_{14}$ & $\mathrm{SC}_{14}$ & $\mathrm{RB}_{14}$ & $\mathrm{SC}_{15}$ & $\mathrm{RB}_{15}$ & $\mathrm{SC}_{14}$ & $\mathrm{RB}_{14}$ & $\mathrm{SC}_{15}$ & $\mathrm{RB}_{15}$ & \\
\hline \multicolumn{15}{|c|}{ Soil bulk density $\left(\mathrm{Mg} \mathrm{m}^{-3}\right)$ at $0-10 \mathrm{~cm}$} \\
\hline Reference $^{(3)}$ & 1.59 & $1.31 *$ & $1.34 *$ & $1.38^{*}$ & $1.42 *$ & - & - & - & - & - & - & - & - & 4.0 \\
\hline Black oat & - & - & - & - & - & $1.38^{*}$ & $1.41^{*}$ & $1.42 *$ & $1.28 *$ & $1.43^{*}$ & $1.44 *$ & $1.38^{*}$ & $1.34 *$ & 4.5 \\
\hline Ryegrass & - & - & - & - & - & $1.33^{*}$ & $1.24 *$ & $1.40^{*}$ & $1.38 *$ & $1.40^{*}$ & $1.32 *$ & $1.32 *$ & $1.34 *$ & 6.1 \\
\hline Wheat & - & - & - & - & - & $1.43^{*}$ & $1.40 *$ & $1.39^{*}$ & $1.39 *$ & $1.41^{*}$ & $1.44 *$ & $1.40^{*}$ & $1.33 *$ & 4.2 \\
\hline Fallow & - & - & - & - & - & $1.41^{*}$ & $1.38^{*}$ & $1.43^{*}$ & $1.33^{*}$ & $1.43^{*}$ & $1.34 *$ & $1.41^{*}$ & $1.36^{*}$ & 4.9 \\
\hline \multicolumn{15}{|c|}{ Soil density $\left(\mathrm{Mg} \mathrm{m}^{-3}\right)$ at $10-20 \mathrm{~cm}$} \\
\hline Reference $^{(3)}$ & 1.66 & $1.40^{*}$ & $1.50^{*}$ & $1.47^{*}$ & $1.43 *$ & - & - & - & - & - & - & - & - & 6.1 \\
\hline Black oat & - & - & - & - & - & 1.56 & 1.58 & 1.60 & 1.55 & 1.54 & 1.59 & $1.47^{*}$ & $1.49 *$ & 5.2 \\
\hline Ryegrass & - & - & - & - & - & 1.55 & $1.50^{*}$ & 1.55 & 1.57 & 1.55 & $1.47^{*}$ & $1.45^{*}$ & $1.44 *$ & 5.3 \\
\hline Wheat & - & - & - & - & - & 1.51 & 1.55 & 1.56 & $1.44 *$ & 1.53 & 1.66 & $1.49^{*}$ & $1.44 *$ & 5.7 \\
\hline Fallow & - & - & - & - & - & 1.61 & 1.59 & 1.58 & 1.61 & 1.61 & $1.53 *$ & $1.51^{*}$ & 1.60 & 3.7 \\
\hline
\end{tabular}

${ }^{(1)} \mathrm{DD}_{14}$, raised bed using double disk (two strips); $\mathrm{SC}_{14}$, soil scarification in November 2014 at $0.25 \mathrm{~cm}$; $\mathrm{RB}_{14}$, raised bed built in November 2014; $\mathrm{SC}_{15}$, soil scarification in November 2015; and $\mathrm{RB}_{15}$, raised bed built in November 2015. ${ }^{(2)}$ From December 2015, samples were collected from the treatments in which soil preparation was associated with the following cover crops in the winter period: black oat (Avena sativa); ryegrass (Lolium multiflorum); wheat (Triticum aestivum); and fallow (control). ${ }^{(3)}$ Means of the reference treatment. CV, coefficient of variation. *Significant differences by Dunnett's test, at $5 \%$ probability. - Data not collected.

Table 2. Total porosity measured in the layers of 0-10 and 10-20 $\mathrm{cm}$ in November 2014, April 2015, December 2015, and April 2016, after soil preparation ${ }^{(1)}$ and the use of cover crops in the winter, in the experimental area in the municipality of Santa Maria, in the state of Rio Grande do Sul, Brazil.

\begin{tabular}{|c|c|c|c|c|c|c|c|c|c|c|c|c|c|c|}
\hline \multirow[t]{2}{*}{ Cover crop $^{(2)}$} & \multicolumn{3}{|c|}{ November 2014} & \multicolumn{2}{|c|}{ April 2015} & \multicolumn{4}{|c|}{ December 2015} & \multicolumn{4}{|c|}{ April 2016} & \multirow{2}{*}{$\begin{array}{l}\mathrm{CV} \\
(\%)\end{array}$} \\
\hline & $\mathrm{DD}_{14}$ & $\mathrm{SC}_{14}$ & $\mathrm{RB}_{14}$ & $\mathrm{SC}_{14}$ & $\mathrm{RB}_{14}$ & $\mathrm{SC}_{14}$ & $\mathrm{RB}_{14}$ & $\mathrm{SC}_{15}$ & $\mathrm{RB}_{15}$ & $\mathrm{SC}_{14}$ & $\mathrm{RB}_{14}$ & $\mathrm{SC}_{15}$ & $\mathrm{RB}_{15}$ & \\
\hline \multicolumn{15}{|c|}{ Total porosity $\left(\mathrm{m}^{3} \mathrm{~m}^{-3}\right)$ at $0-10 \mathrm{~cm}$} \\
\hline Reference $^{(3)}$ & $0.38^{(3)}$ & $0.49^{*}$ & $0.47 *$ & $0.50 *$ & $0.44 *$ & - & - & - & - & - & - & - & - & 5.2 \\
\hline Black oat & - & - & - & - & - & $0.46^{*}$ & $0.47^{*}$ & $0.47 *$ & $0.50^{*}$ & $0.46^{*}$ & $0.45^{*}$ & $0.50^{*}$ & $0.51 *$ & 7.2 \\
\hline Ryegrass & - & - & - & - & - & $0.48^{*}$ & $0.48^{*}$ & $0.46^{*}$ & $0.47^{*}$ & $0.49 *$ & $0.52 *$ & $0.51 *$ & $0.51 *$ & 7.6 \\
\hline Wheat & - & - & - & - & - & $0.45^{*}$ & $0.46^{*}$ & $0.51 *$ & $0.45 *$ & $0.48^{*}$ & $0.47^{*}$ & $0.49^{*}$ & $0.50 *$ & 7.3 \\
\hline Fallow & - & - & - & - & - & 0.43 & $0.44^{*}$ & $0.46^{*}$ & $0.49 *$ & $0.48^{*}$ & $0.51^{*}$ & $0.48^{*}$ & $0.49 *$ & 6.6 \\
\hline \multicolumn{15}{|c|}{ Total porosity $\left(\mathrm{m}^{3} \mathrm{~m}^{-3}\right)$ at $10-20 \mathrm{~cm}$} \\
\hline Reference $^{(3)}$ & $0.40^{(3)}$ & 0.45 & 0.41 & 0.42 & 0.44 & - & - & - & - & - & - & - & - & 9.0 \\
\hline Black oat & - & - & - & - & - & 0.41 & 0.40 & 0.41 & 0.45 & 0.43 & 0.41 & 0.46 & 0.43 & 8.3 \\
\hline Ryegrass & - & - & - & - & - & 0.42 & 0.43 & 0.44 & 0.42 & 0.43 & 0.52 & 0.48 & 0.46 & 12.4 \\
\hline Wheat & - & - & - & - & - & 0.43 & 0.41 & $0.46^{*}$ & $0.45 *$ & 0.41 & 0.37 & $0.45^{*}$ & $0.46^{*}$ & 6.9 \\
\hline Fallow & - & - & - & - & - & 0.39 & 0.40 & 0.41 & $0.44 *$ & 0.41 & 0.41 & $0.45 *$ & 0.42 & 5.3 \\
\hline
\end{tabular}

${ }^{(1)} \mathrm{DD}_{14}$, raised bed using double disk (two strips); $\mathrm{SC}_{14}$, soil scarification in November 2014 at $0.25 \mathrm{~cm}$; $\mathrm{RB}_{14}$, raised bed built in November 2014; $\mathrm{SC}_{15}$, soil scarification in November 2015; and $\mathrm{RB}_{15}$, raised bed built in November 2015. ${ }^{(2)}$ From December 2015, samples were collected from the treatments in which soil preparation was associated with the following cover crops in the winter period: black oat (Avena sativa); ryegrass (Lolium multiflorum); wheat (Triticum aestivum); and fallow (control). ${ }^{(3)}$ Means of the reference treatment. CV, coefficient of variation. *Significant differences by Dunnett's test, at $5 \%$ probability. -Data not collected. 
and after $\mathrm{RB}_{14}$, in plots cultivated with ryegrass. This is indicative that scarification and raised-bed formation in 2015, which increased porosity (total porosity, macroporosity, and microporosity) and decreased soil bulk density, could be dispensed with, since the improvements resulting from their application in November 2014 were still evident.

In the 10-20-cm layer, there were no significant differences for soil bulk density, total porosity, macroporosity, and microporosity measured after cover

Table 3. Macroporosity measured in the layers of $0-10$ and 10-20 cm in November 2014, April 2015, December 2015, and April 2016, after soil preparation ${ }^{(1)}$ and the use of cover crops in the winter, in the experimental area in the municipality of Santa Maria, in the state of Rio Grande do Sul, Brazil.

\begin{tabular}{|c|c|c|c|c|c|c|c|c|c|c|c|c|c|c|}
\hline \multirow[t]{2}{*}{ Cover crop $^{(2)}$} & \multicolumn{3}{|c|}{ November 2014} & \multicolumn{2}{|c|}{ April 2015} & \multicolumn{4}{|c|}{ December 2015} & \multicolumn{4}{|c|}{ April 2016} & \multirow{2}{*}{$\begin{array}{l}\mathrm{CV} \\
(\%)\end{array}$} \\
\hline & $\mathrm{DD}_{14}$ & $\mathrm{SC}_{14}$ & $\mathrm{RB}_{14}$ & $\mathrm{SC}_{14}$ & $\mathrm{RB}_{14}$ & $\mathrm{SC}_{14}$ & $\mathrm{RB}_{14}$ & $\mathrm{SC}_{15}$ & $\mathrm{RB}_{15}$ & $\mathrm{SC}_{14}$ & $\mathrm{RB}_{14}$ & $\mathrm{SC}_{15}$ & $\mathrm{RB}_{15}$ & \\
\hline & \multicolumn{13}{|c|}{ Macroporosity $\left(\mathrm{m}^{3} \mathrm{~m}^{-3}\right)$ at $0-10 \mathrm{~cm}$} & \\
\hline Reference $^{(3)}$ & $0.05^{(3)}$ & $0.18^{*}$ & $0.15^{*}$ & $0.10^{*}$ & 0.06 & - & - & - & - & - & - & - & - & 21.8 \\
\hline Black oat & - & - & - & - & - & 0.09 & 0.09 & 0.09 & $0.13^{*}$ & 0.08 & 0.07 & 0.09 & $0.12 *$ & 27.6 \\
\hline Ryegrass & - & - & - & - & - & 0.09 & $0.12 *$ & 0.08 & 0.08 & 0.09 & $0.12 *$ & $0.10^{*}$ & $0.10^{*}$ & 31.6 \\
\hline Wheat & - & - & - & - & - & 0.07 & 0.09 & $0.12 *$ & $0.10^{*}$ & $0.10^{*}$ & 0.07 & 0.09 & 0.09 & 27.6 \\
\hline \multirow[t]{2}{*}{ Fallow } & - & - & - & - & - & 0.08 & 0.07 & 0.07 & $0.11^{*}$ & $0.09^{*}$ & 0.07 & $0.09 *$ & $0.09 *$ & 22.3 \\
\hline & \multicolumn{13}{|c|}{ Macroporosity $\left(\mathrm{m}^{3} \mathrm{~m}^{-3}\right)$ at $10-20 \mathrm{~cm}$} & \\
\hline Reference $^{(3)}$ & $0.03^{(3)}$ & $0.14 *$ & $0.11 *$ & 0.04 & 0.08 & - & - & - & - & - & - & - & - & 52.1 \\
\hline Black oat & - & - & - & - & - & 0.06 & 0.05 & 0.03 & 0.05 & 0.06 & 0.05 & 0.06 & 0.05 & 41.5 \\
\hline Ryegrass & - & - & - & - & - & 0.07 & 0.06 & 0.06 & 0.04 & 0.06 & 0.06 & $0.07 *$ & $0.08^{*}$ & 36.9 \\
\hline Wheat & - & - & - & - & - & $0.07 *$ & 0.06 & 0.06 & 0.06 & 0.05 & 0.03 & $0.08^{*}$ & $0.06^{*}$ & 28.6 \\
\hline Fallow & - & - & - & - & - & 0.04 & 0.05 & 0.05 & 0.05 & 0.04 & 0.06 & $0.08^{*}$ & 0.05 & 28.3 \\
\hline
\end{tabular}

${ }^{(1)} \mathrm{DD}_{14}$, raised bed using double disk (two strips); $\mathrm{SC}_{14}$, soil scarification in November 2014 at $0.25 \mathrm{~cm}$; $\mathrm{RB}_{14}$, raised bed built in November $2014 ; \mathrm{SC}_{15}$, soil scarification in November 2015; and $\mathrm{RB}_{15}$, raised bed built in November 2015. ${ }^{(2)}$ From December 2015, samples were collected from the treatments in which soil preparation was associated with the following cover crops in the winter period: oat (Avena sativa); RG, ryegrass (Lolium multiflorum); $\mathrm{WH}$, wheat (Triticum aestivum); and FW, fallow (control). ${ }^{3}$ Means of the reference treatment. CV, coefficient of variation. *Significant differences by Dunnett's test, at $5 \%$ probability. -Data not collected.

Table 4. Microporosity measured in the layers of 0-10 and 10-20 cm in November 2014, April 2015, December 2015, and April 2016, after soil preparation ${ }^{(1)}$ and the use of cover crops in the winter, in the experimental area in the municipality of Santa Maria, in the state of Rio Grande do Sul, Brazil.

\begin{tabular}{|c|c|c|c|c|c|c|c|c|c|c|c|c|c|c|}
\hline \multirow[t]{2}{*}{ Cover crop ${ }^{(2)}$} & \multicolumn{3}{|c|}{ November 2014} & \multicolumn{2}{|c|}{ April 2015} & \multicolumn{4}{|c|}{ December 2015} & \multicolumn{4}{|c|}{ April 2016} & \multirow{2}{*}{$\begin{array}{l}\mathrm{CV} \\
(\%)\end{array}$} \\
\hline & $\mathrm{DD}_{14}$ & $\mathrm{SC}_{14}$ & $\mathrm{RB}_{14}$ & $\mathrm{SC}_{14}$ & $\mathrm{RB}_{14}$ & $\mathrm{SC}_{14}$ & $\mathrm{RB}_{14}$ & $\mathrm{SC}_{15}$ & $\mathrm{RB}_{15}$ & $\mathrm{SC}_{14}$ & $\mathrm{RB}_{14}$ & $\mathrm{SC}_{15}$ & $\mathrm{RB}_{15}$ & \\
\hline \multicolumn{15}{|c|}{ Microporosity $\left(\mathrm{m}^{3} \mathrm{~m}^{-3}\right)$ at $0-10 \mathrm{~cm}$} \\
\hline Reference $^{(3)}$ & $0.33^{(3)}$ & 0.31 & 0.32 & $0.40^{*}$ & $0.39 *$ & - & - & - & - & - & - & - & - & 8.3 \\
\hline Black oat & - & - & - & - & - & 0.37 & $0.38^{*}$ & $0.38^{*}$ & 0.37 & $0.38^{*}$ & $0.38^{*}$ & $0.41 *$ & $0.39 *$ & 7.1 \\
\hline Ryegrass & - & - & - & - & - & $0.38^{*}$ & $0.38^{*}$ & $0.38^{*}$ & $0.39 *$ & $0.40^{*}$ & $0.40^{*}$ & $0.41 *$ & $0.41^{*}$ & 6.3 \\
\hline Wheat & - & - & - & - & - & $0.38^{*}$ & 0.37 & $0.39 *$ & 0.36 & $0.38^{*}$ & $0.40^{*}$ & $0.41 *$ & $0.41 *$ & 6.6 \\
\hline Fallow & - & - & - & - & - & 0.36 & 0.37 & $0.39 *$ & $0.38^{*}$ & $0.39 *$ & $0.39 *$ & $0.39 *$ & $0.40^{*}$ & 7.7 \\
\hline \multicolumn{15}{|c|}{ Microporosity $\left(\mathrm{m}^{3} \mathrm{~m}^{-3}\right)$ at $10-20 \mathrm{~cm}$} \\
\hline Reference $^{(3)}$ & $0.37^{(3)}$ & $0.31 *$ & $0.30^{*}$ & 0.38 & 0.36 & - & - & - & - & - & - & - & - & 4.9 \\
\hline Black oat & - & - & - & - & - & 0.35 & 0.35 & 0.38 & 0.37 & 0.37 & 0.36 & 0.39 & 0.39 & 4.9 \\
\hline Ryegrass & - & - & - & - & - & 0.36 & 0.36 & 0.38 & 0.37 & 0.37 & 0.46 & 0.41 & 0.39 & 14.4 \\
\hline Wheat & - & - & - & - & - & 0.36 & 0.35 & $0.39 *$ & 0.36 & 0.37 & 0.35 & 0.38 & $0.40^{*}$ & 3.9 \\
\hline Fallow & - & - & - & - & - & 0.35 & 0.35 & 0.37 & 0.37 & 0.37 & 0.36 & 0.37 & 0.37 & 3.0 \\
\hline
\end{tabular}

${ }^{(1)} \mathrm{DD}_{14}$, raised bed using double disk (two strips); $\mathrm{SC}_{14}$, soil scarification in November 2014 at $0.25 \mathrm{~cm}$; $\mathrm{RB}_{14}$, raised bed built in November 2014; $\mathrm{SC}_{15}$, soil scarification in November 2015; and $\mathrm{RB}_{15}$, raised bed built in November 2015. ${ }^{(2)}$ From December 2015, samples were collected from the treatments in which soil preparation was associated with the following cover crops in the winter period: black oat (Avena sativa); ryegrass (Lolium multiflorum); wheat (Triticum aestivum); and fallow (control). ${ }^{(3)}$ Means of the reference treatment. CV, coefficient of variation. *Significant differences by Dunnett's test, at $5 \%$ probability. -Data not collected. 
crops were sown and in November 2014 following the $\mathrm{DD}_{14}$ treatment. In absolute numbers, all treatments showed a decrease in soil bulk density. It should be noted that the persistence of these effects could be intensified or minimized, depending on the intensity of the factors that control soil reconsolidation and resilience, such as precipitation, wetting and drying cycles, and species cultivated (Six et al., 2004); most of these factors are not controllable in the field.

There is no clear evidence that any of the evaluated crop species affected soil bulk density, total porosity, macroporosity, or microporosity measured before (December 2015 and April 2016) and after (DD 14 , November 2014, and April 2015) the introduction of cover crops. Therefore, it was not possible to verify, in a single crop season, if any of the cover crops would prolong the changes in soil structure promoted by scarification and raised-bed formation. Similarly, soil bulk density, total porosity, microporosity, and macroporosity were not altered after one year of cover crop cultivation in a study conducted by Cardoso et al. (2013). According to Stumpf et al. (2014), it took at least three years for a cover crop of Poaceae (grasses) to improve the physical structure of the analyzed soil.

RP measured in December 2015, soon after soybean sowing (Figure 1 A), and in April 2016, at the end of crop development (Figure $1 \mathrm{~B}$ ), also did not allow to clearly conclude whether any crop species modified soil mechanical strength, for all seasons and soil preparations. The most significant differences in RP were found between scarification and raised-bed formation, regardless of the year when they were applied. RP was decreased by scarification in the 0-30$\mathrm{cm}$ layer, by $\mathrm{RB}_{14}$ in the $0-10-\mathrm{cm}$ layer, and by $\mathrm{RB}_{15}$ in the $0-15-\mathrm{cm}$ layer. These results are in alignment with the soil bulk density decrease and total porosity increase in the $0-10-\mathrm{cm}$ layer, as previously discussed. Moreover, the mobilization of the sowing row shown in the RP graphs coincided with the depths up to which the action of the treatments was observed, i.e., the 25$\mathrm{cm}$ layer for $\mathrm{SC}_{14}$ at sowing time and the $30-\mathrm{cm}$ layer for $\mathrm{SC}_{15}$. The raised bed built in 2014 was seeded using a double-disk mechanism, which acted at approximately $7-\mathrm{cm}$ depth, whereas the one built in 2015 was made using a furrowing rod for seed deposition, which acted at approximately $18-\mathrm{cm}$ depth.

When measured in both 2014 and 2015, RP below $15 \mathrm{~cm}$ was similar for $\mathrm{RB}_{14}$ and $\mathrm{RB}_{15}$. This is indicative that this RP value represents soil mechanical resistance due to historical land use, since there was no soil mobilization below $15 \mathrm{~cm}$ in the period from November 2014 to April 2016. Based on this result, $\mathrm{SC}_{14}$ kept soil resistance to mechanical penetration low until December 2015 (Figure $1 \mathrm{~A}$ ), and this resistance continued up to April 2016 (Figure 1 B). Further evidence that repeating soil scarification is unnecessary before 18 months is that no significant differences were observed for the RP values obtained for $\mathrm{SC}_{15}$ and $\mathrm{SC}_{14}$, when compared in April 2016 (Figure $1 \mathrm{~B}$ ). The same treatments $\left(\mathrm{SC}_{15}\right.$ vs. $\left.\mathrm{SC}_{14}\right)$ also showed soil with lower water content $\left(0.33 \mathrm{~m}^{3} \mathrm{~m}^{-3}\right)$ in December 2015 (Figure 1). In addition, RP values in the scarified treatments remained below $2 \mathrm{MPa}$, which is usually considered limiting for root development (Bortoluzzi et al., 2014). It should be pointed out that RP varies significantly with changes in soil water content, since water reduces the friction between soil particles (Assis et al., 2009). Therefore, in soils with a higher moisture content, a reduction in RP is favored, as was the case in April 2016.

In relation to Ks (Figure $2 \mathrm{~B}$ ), in the $0-10$-cm layer, all soil preparations carried out in November 2015 and $\mathrm{SC}_{14}$ resulted in higher values, which differed from those obtained for $\mathrm{RB}_{14}$. Cover crops, however, did not affect $\mathrm{Ks}$. In the $10-20-\mathrm{cm}$ layer, $\mathrm{SC}_{15}$ maintained the highest conductivity, followed by $\mathrm{SC}_{14}$; the lowest values were recorded for the raised beds built in both experimental years. Therefore, the duration of the effects of soil preparation depends on the assessed soil property. According to Drescher et al. (2016) and Reichert et al. (2009), RP is a better parameter than soil bulk density or total porosity for supporting the decision whether or not to repeat soil scarification. Drescher et al. (2016) also highlighted that, together with RP, Ks and infiltration rate were the most sensitive parameters for detecting the duration of changes in soil structure. Over shorter periods, such as a crop season, the evaluation of soil bulk density and total porosity allows identifying changes in soil volume occupation due to solid particles or void spaces, whereas, for longer periods, Ks and infiltration rate are better indicators for the identification of changes in soil water transport (Drescher et al., 2016). Therefore, the soil bulk density, total porosity, RP, and Ks measurements are indicative that there is no need to repeat scarification before 18 months.

Pesq. agropec. bras., Brasília, v.53, n.11, p.1230-1238, Nov. 2018 DOI: 10.1590/S0100-204X2018001100005 


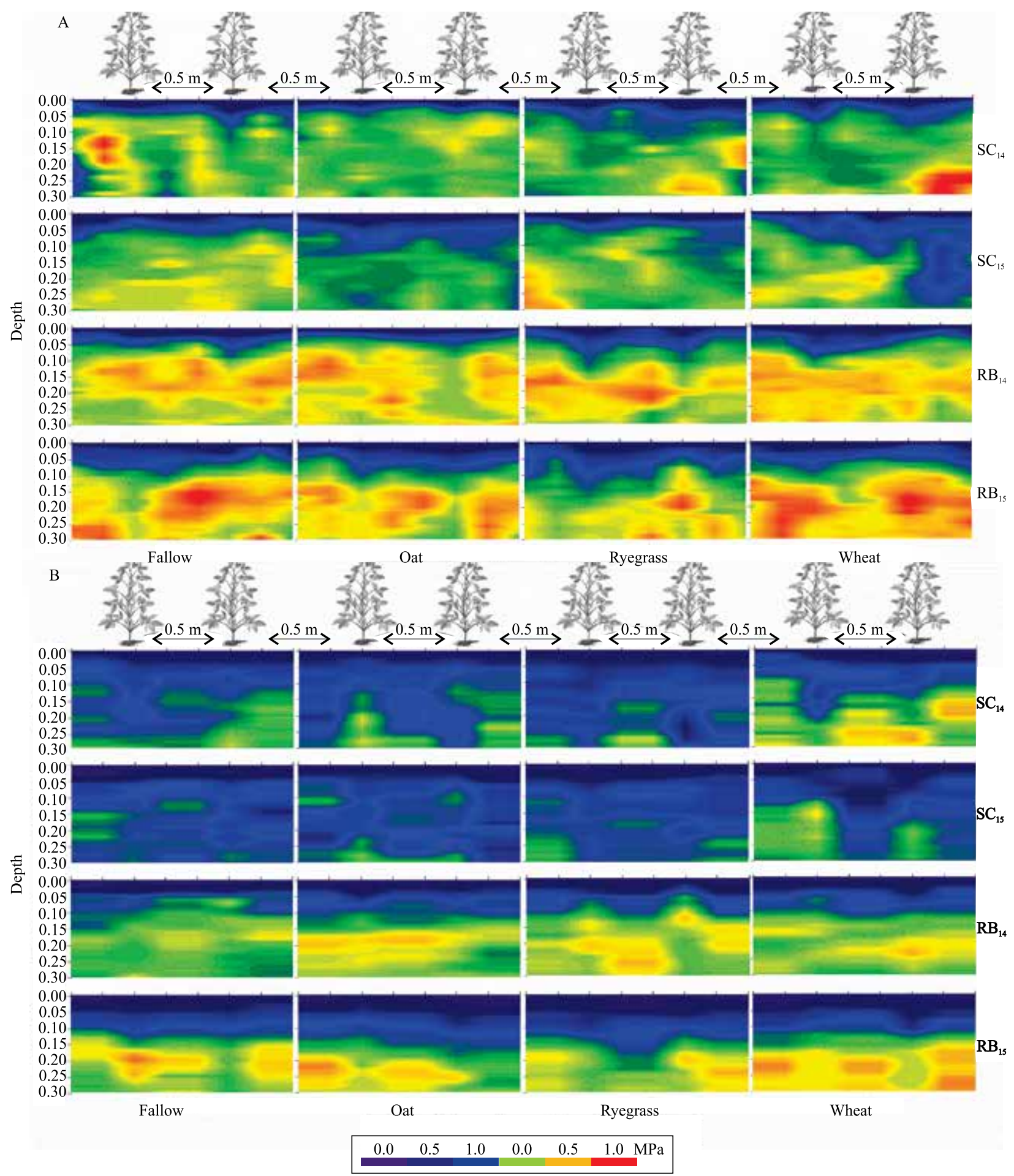

Figure 1. Soil resistance to mechanical penetration perpendicular to sowing grooves in December 2015 (A) and April 2016 (B), in the experimental area in the municipality of Santa Maria, in the state of Rio Grande do Sul, Brazil. Soil preparation (horizontal): $\mathrm{SC}_{14}$, soil scarification in November 2014; $\mathrm{SC}_{15}$, soil scarification in November 2015; $\mathrm{RB}_{14}$, raised bed built in November 2014; and $\mathrm{RB}_{15}$, raised bed built in November 2015. Cover plants (vertical): black oat (Avena sativa), ryegrass (Lolium multiflorum), and wheat (Triticum aestivum), besides fallow (control). Average soil water content of $0.33 \mathrm{~m}^{3} \mathrm{~m}^{-3}$ (A) and $0.35 \mathrm{~m}^{3} \mathrm{~m}^{-3}(\mathrm{~B})$ in the layer of $0.0-0.30 \mathrm{~m}$. 
Soybean grain yield (Figure 2 A) was not significantly affected by cover crops. However, soil preparations resulted in different yields: higher values for $\mathrm{RB}_{15}$ and $\mathrm{SC}_{15}$, which did not differ significantly from those for $\mathrm{SC}_{14}$. The lowest yield was obtained for $\mathrm{RB}_{14}$, possibly due to the reduced mobilization in the sowing furrow opened by the double disk; this mechanism, because it lacks a depth effect, was not efficient in reducing the compacted layer in the furrow (Sartori et al., 2015). Furthermore, the 2015/2016 harvest was affected by the El Niño, which caused high rainfall volumes, favoring
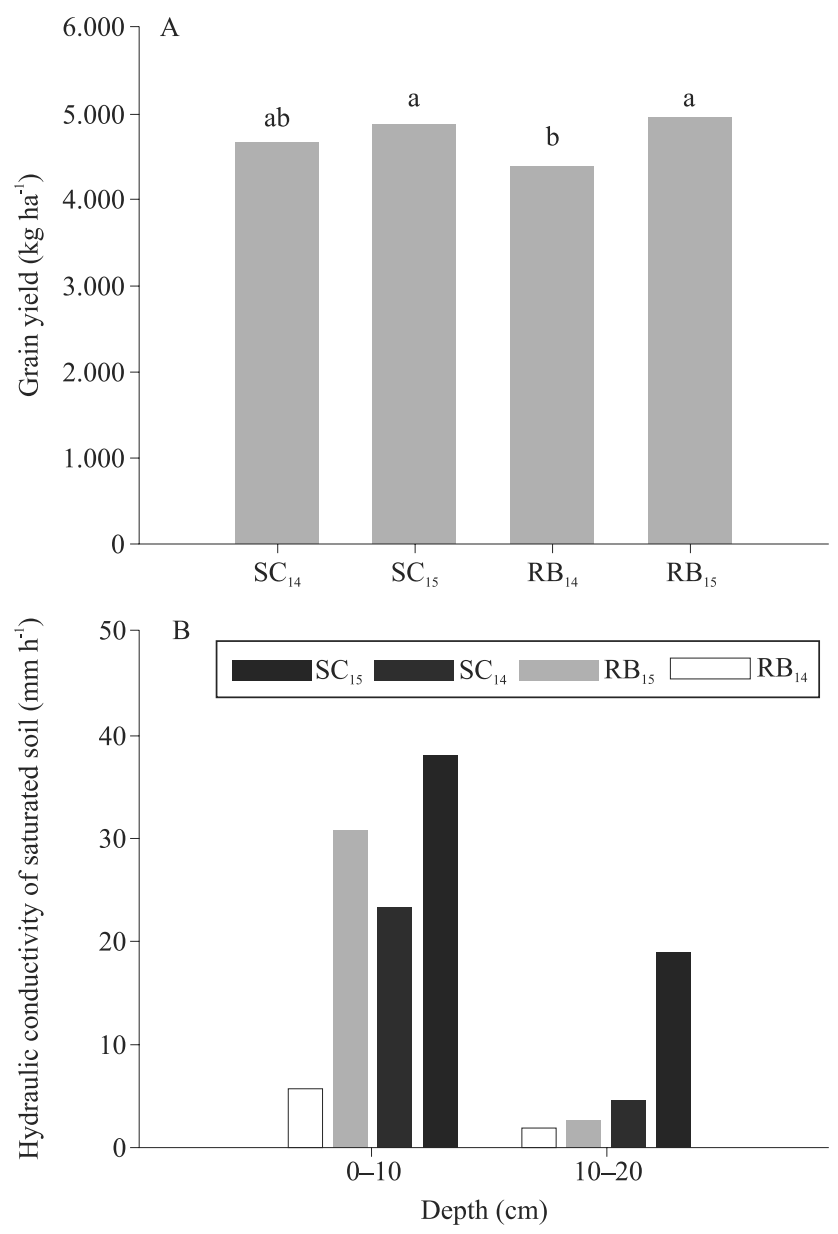

Figure 2. Grain yield of the soybean (Glycine max) cultivar BMX Valente RR (A) and hydraulic conductivity of saturated soil (B). $\mathrm{SC}_{14}$, soil scarification in November 2014; $\mathrm{SC}_{15}$, soil scarification in November 2015; $\mathrm{RB}_{14}$, raised bed built in November 2014; and $\mathrm{RB}_{15}$, raised bed built in November 2015. *Means followed by different letters in the bars differ from each other by Tukey's test, at 5\% probability. Coefficients of variation: A, 9\%; and B, 48 and $24 \%$ for the $0-10$ and $10-20-\mathrm{cm}$ layers, respectively.
$\mathrm{RB}_{15}$, which had been built more recently and was not affected by erosion as $\mathrm{RB}_{14}$, allowing the plants to grow without excess water due to its more efficient drainage. Therefore, in order to reuse raised beds, it is necessary to assess probable climatic conditions for the next crop season, to harvest the summer crop while the soil is dry, and to ensure that the drainage grooves will not be obstructed, otherwise there will be yield losses, as observed in the present study. In addition, the current depth of the furrow, associated with soil type, will also affect furrow depth in the following crop.

The highest grain yields were obtained using the treatments with the highest soil mobilization and were related to decreases in RP, soil bulk density, and total porosity, as well as to the increase in Ks. The duration of the benefits of scarification for up to 18 months, as also observed by Drescher et al. (2016), affected grain yield, which decreased in $4.3 \%$ for $\mathrm{S}_{14}$ compared with $\mathrm{SC}_{15}$. These results indicate that a new scarification will require greater tensile strength from the farm equipment, causing a higher fuel and engine power consumption by the tractor, increasing production costs (Vizzotto, 2014).

\section{Conclusions}

1. Changes in soil density, total porosity, and penetration resistance in an Alfisol were noticeable for at least 18 months due to mechanical scarification, but not to raised-bed formation, reflecting in soybean (Glycine max) yield in the second harvest.

2. No effect was observed for the cover crops ryegrass (Lolium multiflorum), oat (Avena sativa), and wheat (Triticum aestivum), in a single crop year, on the maintenance of soil physical attributes and on soybean yield.

\section{References}

ABREU, S.L.; REICHERT, J.M.; REINERT, D.J. Escarificação mecânica e biológica para a redução da compactação em Argissolo franco-arenoso sob plantio direto. Revista Brasileira de Ciência do Solo, v.28, p.519-531, 2004. DOI: 10.1590/S010006832004000300013.

ÁlVAREZ, C.R.; DUGGAN, M.T.; CHAMORRO, E.R.; D’AMBROSIO, D.; TABOADA, M.A. Descompactación de suelos franco limosos en siembra directa: efectos sobre las propiedades edáficas y los cultivos. Ciencia del Suelo, v.27, p.159-169, 2009.

ASSIS, R.L. de; LAZARINI, G.D.; LANÇAS, K.P.; CARGNELUTTI FILHO, A. Avaliação da resistência do solo à penetração em diferentes solos com a variação do teor de água. 
Engenharia Agrícola, v.29, p.558-568, 2009. DOI: 10.1590/ S0100-69162009000400006.

BORTOLUZZI, E.C.; PARIZE, G.L.; KORCHAGIN, J.; SILVA, V.R. da; RHEINHEIMER, D. dos S.; KAMINSKI, J. Soybean root growth and crop yield in response to liming at the beginning of a no-tillage system. Revista Brasileira de Ciência do Solo, v.38, p.262-271, 2014. DOI: 10.1590/S0100-06832014000100026.

CALONEGO, J.C.; GOMES, T.C.; SANTOS, C.H. dos; TIRITAN, C.S. Desenvolvimento de plantas de cobertura em solo compactado. Bioscience Journal, v.27, p.289-296, 2011.

CARDOSO, D.P.; SILVA, M.L.N.; CARVALHO, G.J. de; FREITAS, D.A.F. de; AVANZI, J.C. Espécies de plantas de cobertura no recondicionamento químico e físico do solo. Revista Brasileira de Ciências Agrárias, v.8, p.375-382, 2013. DOI: 10.5039/agraria.v8i3a2421.

DRESCHER, M.S.; REINERT, D.J.; DENARDIN, J.E.; GUBIANI, P.I.; FAGANELlO, A.; DRESCHER, G.L. Duração das alterações em propriedades físico-hídricas de Latossolo argiloso decorrentes da escarificação mecânica. Pesquisa Agropecuária Brasileira, v.51, p.159-168, 2016. DOI: 10.1590/ S0100-204X2016000200008.

FEHR, W.R.; CAVINESS, C.E. Stages of soybean development. Ames: Iowa State University of Science and Technology, 1977. 12p. (Special report, 80).

GIACOMELI, R.; MARCHESAN, E.; SARTORI, G.M.S.; DONATO, G.; SILVA, P.R.F da; KAISER, D.R.; ARAMBURU, B.B. Escarificação do solo e sulcadores em semeadora para cultivo de milho em Planossolos. Pesquisa Agropecuária Brasileira, v.51, p.261-270, 2016. DOI: 10.1590/S0100-204X2016000300008.

GOMES, A. da S.; SILVA, C.A.S. da; PARFITT, J.M.B.; PAULETTO, E.A.; PINTO, L.F.S. Caracterização de indicadores da qualidade do solo, com ênfase às áreas de várzea do Rio Grande do Sul. Pelotas: Embrapa Clima Temperado, 2006. 41p. (Embrapa Clima Temperado. Documentos, 169).

IRGA. Instituto Riograndense do Arroz. Soja em rotação com arroz. Available at: <http://www.irga.rs.gov.br/conteudo/4215/ safras>. Accessed on: Nov. 32016.

LIBARDI, P.L. Dinâmica da água no solo. São Paulo: Edusp, 2005. 335p.

MISSIO, E.L.; RUBIN, S. de A.L.; GABE, N.L.; OZELAME, J.G. Desempenho de genótipos de soja em solo hidromórfico de várzea. Pesquisa Agropecuária Gaúcha, v.16, p.23-29, 2010.

NICOLOSO, R. da S.; AMADO, T.J.C.; SCHNEIDER, S.; LANZANOVA, M.E.; GIRARDELLO, V.C.; BRAGAGNOLO, J. Eficiência da escarificação mecânica e biológica na melhoria dos atributos físicos de um Latossolo muito argiloso e no incremento do rendimento de soja. Revista Brasileira de Ciência do Solo, v.32, p.1723-1734, 2008. DOI: 10.1590/S0100-06832008000400037.
NUNES, M.R.; PAULETTO, E.A.; DENARDIN, J.E.; FAGANELLO, A.; PINTO, L.F.S.; SCHEUNEMANN, T. Persistência dos efeitos da escarificação sobre a compactação de Nitossolo sob plantio direto em região subtropical úmida. Pesquisa Agropecuária Brasileira, v.49, p.531-539, 2014. DOI: 10.1590/S0100-204X2014000700005.

REICHERT, J.M.; KAISER, D.R.; REINERT, D.J.; RIQUELME, U.F.B. Variação temporal de propriedades físicas do solo e crescimento radicular de feijoeiro em quatro sistemas de manejo. Pesquisa Agropecuária Brasileira, v.44, p.310-319, 2009. DOI: 10.1590/S0100-204X2009000300013.

REINERT, D.J.; REICHERT, J.M. Coluna de areia para medir a retenção de água no solo - protótipos e teste. Ciência Rural, v.36, p.1931-1935, 2006. DOI: 10.1590/S0103-84782006000600044.

SANTOS, H.G. dos; JACOMINE, P.K.T.; ANJOS, L.H.C. dos; OLIVEIRA, V.A. de; LUMBRERAS, J.F.; COELHO, M.R.; ALMEIDA, J.A. de; CUNHA, T.J.F.; OLIVEIRA, J.B. de. Sistema brasileiro de classificação dos solos. 3.ed. rev. e ampl. Brasília: Embrapa, 2013. 353p.

SARTORI, G.M.S.; MARCHESAN, E.; DAVID, R. de; CARLESSO, R.; PETRY, M.T.; DONATO, G.; CARGNELUTTI FILHO, A.; SILVA, M.F da. Soybean yield under different planting systems and border irrigation on Alfisols. Pesquisa Agropecuária Brasileira, v.50, p.1139-1149, 2015. DOI: 10.1590/ S0100-204X2015001200003.

SILVA, C.A.S. da; PARFITT, J.M.B.; SILVA, J.J.C. da; THEISEN, G. (Ed.). Drenagem superficial para cultivos rotacionados em solos de várzea. Pelotas: Embrapa Clima Temperado, 2008. 23p.

SIX, J.; BOSSUYT, H.; DEGRYZE, S.; DENEF, K. A history of research on the link between (micro)aggregates, soil biota, and soil organic matter dynamics. Soil and Tillage Research, v.79, p.7-31, 2004. DOI: 10.1016/j.still.2004.03.008.

STUMPF, L.; PAULETTO, E.A.; CASTRO, R.C. de; PINTO, L.F.S.; FERNANDES, F.F.; BARBOZA, F. da S.; FRANCO, A.M.P.; GONÇALVES, F.C. Estrutura de um solo construído cultivado com diferentes espécies de poáceas. Ciência Rural, v.44, p.2171-2177, 2014. DOI: 10.1590/0103-8478cr20131514.

TEDESCO, M.J.; GIANELLO, C.; ANGHINONI, I.; BISSANI, C.A.; CAMARGO, F.A.O.; WIETHÖLTER, S. (Ed.). Manual de adubação e de calagem para os estados do Rio Grande do Sul e Santa Catarina. 10.ed. Porto Alegre: Sociedade Brasileira de Ciência do Solo, Núcleo Regional Sul, 2004. 400p.

VIZZOTTO, V.R. Desempenho de mecanismos sulcadores em semeadora-adubadora sobre os atributos físicos do solo em várzea no comportamento da cultura da soja (Glycine max L). 2014. 78p. Tese (Doutorado) - Universidade Federal de Santa Maria, Santa Maria. 